\title{
Publisher Correction: The Scales Project, a cross-national dataset on the interpretation of thermal perception scales
}

Marcel Schweiker D, Amar Abdul-Zahra, Maíra André, Farah Al-Atrash, Hanan Al-Khatri,

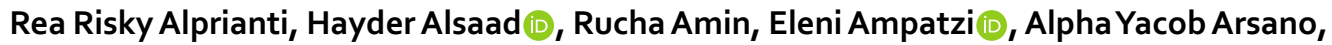
Montazami Azadeh, Elie Azar (D), Bannazadeh Bahareh, Amina Batagarawa, Susanne Becker D, Carolina Buonocore, Bin Cao, Joon-Ho Choi, Chungyoon Chun, Hein Daanen, Siti Aisyah Damiati D, Lyrian Daniel (D, Renata De Vecchi (D, Shivraj Dhaka, Samuel Domínguez-Amarillo, Edyta Dudkiewicz (D), Lakshmi Prabha Edappilly (D, Jesica Fernández-Agüera, Mireille Folkerts, Arjan Frijns, Gabriel Gaona $\mathbb{D}$, Vishal Garg $\mathbb{D}$,

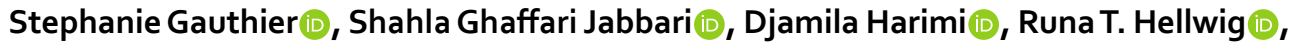
Gesche M. Huebner $\left(\mathbb{D}\right.$, Quan Jin $\mathbb{D}^{\mathrm{D}}$, Mina Jowkar, Renate Kania, Jungsoo Kim $\mathbb{D}$,

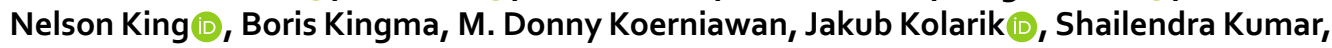
Alison Kwok, Roberto Lamberts $\mathbb{D}$, Marta Laska $\mathbb{D}$, M. C. Jeffrey Lee, Yoonhee Lee, Vanessa Lindermayr, Mohammadbagher Mahaki, Udochukwu Marcel-Okafor, Laura Marín-Restrepo (D, Anna Marquardsen, Francesco Martellotta (D, Jyotirmay Mathur, Gráinne McGill(D, Isabel Mino-Rodriguez $\mathbb{D}$, Di Mou, Bassam Moujalled $\mathbb{D}_{\text {, Mia Nakajima, }}$

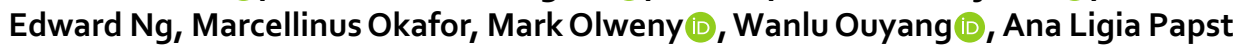

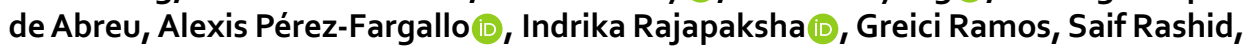
Christoph F. Reinhart, Ma. Isabel Rivera, Mazyar Salmanzadeh, Karin Schakib-Ekbatan, Stefano Schiavon (D), Salman Shooshtarian, Masanori Shukuya, Veronica Soebarto, Suhendri, Mohammad Tahsildoost $\mathbb{D}$, Federico Tartarini $\mathbb{D}$, Despoina Teli $\mathbb{D}$, Priyam Tewari, SamarThapa $\left(\mathbb{D}\right.$, Maureen Trebilcock $\left(\mathbb{D}\right.$, Jörg Trojan $\mathbb{D}^{\mathrm{D}}$, Ruqayyatu B. Tukur, Conrad Voelker, Yeung Yam, LiuYang, Gabriela Zapata-Lancaster $(D$, Yongchao Zhai, Yingxin Zhu \& Zahra Sadat Zomorodian (D)

Correction to: Scientific Data https://doi.org/10.1038/s41597-019-0272-6, published online 26 November 2019

During the typesetting process, errors were introduced into the affiliations of authors Maureen Trebilcock and Yoonhee Lee. This has been corrected in both the HTML and PDF versions of this Data Descriptor.

(1) Open Access This article is licensed under a Creative Commons Attribution 4.0 International License, which permits use, sharing, adaptation, distribution and reproduction in any medium or format, as long as you give appropriate credit to the original author(s) and the source, provide a link to the Creative Commons license, and indicate if changes were made. The images or other third party material in this article are included in the article's Creative Commons license, unless indicated otherwise in a credit line to the material. If material is not included in the article's Creative Commons license and your intended use is not permitted by statutory regulation or exceeds the permitted use, you will need to obtain permission directly from the copyright holder. To view a copy of this license, visit http://creativecommons.org/licenses/by/4.0/.

(c) The Author(s) 2020 